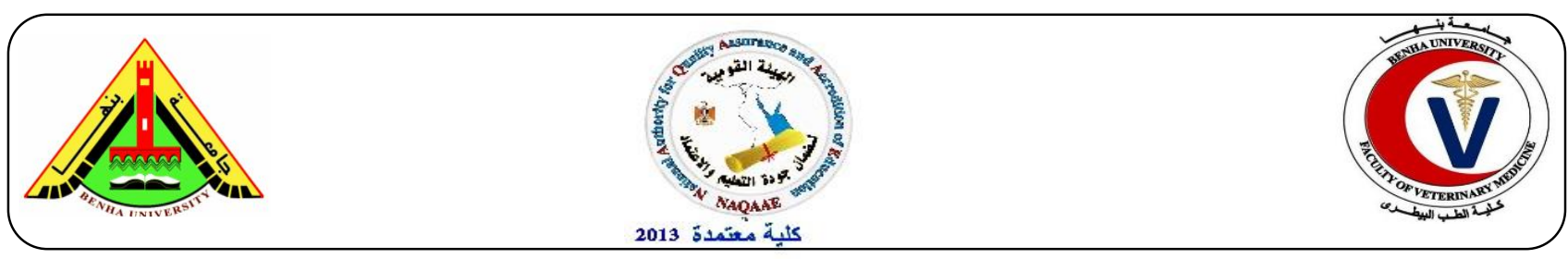

\title{
Proanthocyanidin inhibit the development of diethylnitrosoamine induced premalignant phenotype in rat chemical hepatocarcinogensis model
}

\author{
Samy A. Hussein, Yakoot A. EL-senosi and Kamilia K. El- Hajjar
}

Department of Biochemistry, Faculty of Veterinary Medicine, Benha University

\section{A B S T R A C T}

Proanthocyanidin was shown to exert anti-inflammatory, antioxidant, hepatoprotective properties, and anticancer activity. This study was done to investigate the protective effects of Proanthocyanidin on Diethylnitrosamine induced hepatocarcinogensis in rats. Fourty five male albino rats were divided into three groups. Group I: (normal control group): rats administered distilled water only. Group II: rats received Diethylnitrosamine (200 mg/kg b.wt/i.p), 2 weeks later rats received $(2 \mathrm{ml} / \mathrm{kg}$ b.wt) Carbon tetrachloride (CCl4) orally at $1: 1$ dilution in corn oil as a promoter of carcinogenic effect. DEN and CCl4 injections were repeated once again after 1 month from the first DEN injection. Group III: rats received $\mathrm{DEN}+\mathrm{CCl} 4$ then treated with proanthocyanidin at a dose of $(100 \mathrm{mg} / \mathrm{kg}$ b.wt/orally) dissolved in DMSO $7 \%$ for 6 weeks. All animals were sacrificed after the end of experiment. DEN induced HCC showed significant increase in hepatic marker enzymes (ALT and ALP), total bilirubin and alpha fetoprotein (AFP) with marked decrease in serum albumin concentration. Also, the results of molecular analysis in liver tissue revealed significant up-regulation in TNF- $\alpha$ gene expression level. Conversely, downregulation in tumor suppressor gene $\mathrm{p} 53$ and Cyp2E1 gene expression compared with control group. Treatment with proanthocyanidin to DEN induced HCC protects the liver cells from damage by regulating the biochemical parameters. The obtained results suggest that proanthocyanidin can inhibit the proliferation of HCC cells through inducing tumor cell apoptosis via activation of the p53 pathway and detoxification enzyme Cyp2E1 and inhibition of TNF- $\alpha$ overexpression. Proanthocyanidin may thus be used as a potentially promising agent to inhibit HCC cell proliferation and may be a novel natural product for the management treatment of HCC.

Keywords: Diethylnitrosamine, Hepatocarcinogensis, Proanthocyanidin, Detoxification Enzyme, P53.

(http://www.bvmj.bu.edu.eg) (BVMJ-35(2): 612-624, 2018)

\section{INTRODUCTION}

Hepatocellular carcinoma (HCC) is a malignant neoplasm of hepatocytes and constitutes more than $80 \%$ of primary malignant liver neoplasms (Satir, 2007). Worldwide, liver cancer is the fifth most common malignancy and the third most common cause of cancer death (Kung et al.,
2010). The major avoidable causes of cancer are smoking, dietary imbalances, chronic infections and hormonal factors which are influenced primarily by lifestyle, other causal factors in human cancer are excessive sun exposure, viruses (e.g., human papilloma virus and cervical cancer) and 
pharmaceuticals (phenacetin, some chemotherapy agents, diethylstilbestrol, and estrogen) (Gold et al., 2002). Many hepatocarcinogens such as aflatoxins, acetylaminofluorene 3 and diethylnitrosamine have been successfully used to develop hepatocarcinogenesis in animals (Mukherjee et al., 2009). Diethyl nitrosamine (DEN) is a potent hepatocarcinogenic nitrosamine, present in cheddar cheese, cured and fried meals, alcoholic beverages, cosmetics, agricultural chemicals and pharmaceutical agents, ground water having high level of nitrate (Mahmoud and AbdulHamid, 2012). Carbon tetrachloride (CCl4) is classified as a possible human carcinogen based on inadequate evidence of carcinogenicity in humans but sufficient evidence in animals. However, there are major deficiencies in the available cancer studies. Animal studies suggest that the carcinogenicity of carbon tetrachloride is secondary to its hepatotoxic effects, indicating a possible threshold (Provincial, 2010).

A number of modern drugs have been isolated from natural sources and many of these isolations were based on the uses of the agents in traditional medicine. Natural proanthocyanidins are biologically active polyphenolic flavonoids which are known as oligomeric proanthocyanidins. These proanthocyanidins have demonstrated a marked spectrum of biological, pharmacological, therapeutic, and chemoprotective properties against oxygen free radicals and oxidative stress (Mansouri et al., 2011). Proanthocyanidins are polyphenolic compounds that can be found in the plant physiology of several plant species, are mainly concentrated in tree barks and outer skins of seeds. Grape seeds are one of the richest sources of proanthocyanidins (Nakamura et al.,2003).
Consequently, the present study aimed to evaluate the beneficial effects and chemopreventive potential of proanthocyanidins (the active ingredient of grape seed extract) on diethylnitrosamineinduced liver cancer in rats through evaluation of some serum liver biomarkers and molecular analysis of hepatic phase I enzyme (CYP 2E1), tumor suppressor gene P53 and pro-inflammatory cytokines TNF- $\alpha$ gene expression in hepatic tissues.

The present study investigated the curative and treatment effects of proanthocyanidins (the active ingredient of grape seed extract) were studied after hepatic carcinoma induction by DEN via its chemopreventive and apoptotic properties.

\section{Materials and methods}

\subsection{Experimental animals :}

Forty-five white male albino rats of 6- 8 weeks old and weighing 150 - $180 \mathrm{~g}$ housed in separated metal cages and kept at constant environmental and nutritional conditions throughout the period of experiment. The animals fed on constant ration and water was supplied ad- labium .

\subsection{Chemicals and antioxidant:}

All chemicals were of analytical grade and obtained from standard commercial suppliers. The antioxidant and chemicals used in the present study were:

2.2.1. Diethylnitrosamine (DEN) and Carbon tetrachloride (CCl4) were Purchased from SIGMA Chemical Co. (St. Louis, MO, USA) . Induction of Hepatocarcinogenesis:

Hepatocellular carcinoma was induced in rats by I. P injection of DEN in normal saline (200 $\mathrm{mg} / \mathrm{kg}$ b.wt), 2 weeks later rats received (2 $\mathrm{ml} / \mathrm{kg}$ b.wt) $\mathrm{CCl} 4$ orally at 1:1 dilution in corn oil as a promoter of carcinogenic effect. DEN and $\mathrm{CCl} 4$ administration were repeated once again after 1 month from the first DEN injection. (Hassan et al.,2014). 
2.2.2. Grape Seed Proanthocyanidins Extract was purchased from (Al Debeiky Pharma Company for Pharmaceutical industries, Al Obour, Cairo, Egypt). Proanthocyanidins was dissolved in DMSO and diluted to the appropriate concentration by sterilized saline solution and administered orally to rats at a dose level of $(100 \mathrm{mg} / \mathrm{kg} \mathrm{b.wt)} \mathrm{(Hamza} \mathrm{et}$ al.,2018).

\subsection{Experimental design:}

After acclimatization to the laboratory conditions, the animals were randomly divided into three groups (15 rats each) placed in individual cages and classified as follow :

Group I: Control Normal group:

Consisted of 15 male rats fed with ordinary diet only without any treatment during the entire experimental period of 14 weeks.

Group II: DEN- induced hepatocarcinogenesis group:

Consisted of 15 male rats received DEN in normal saline $(200 \mathrm{mg} / \mathrm{kg}$ b.wt) by I.P injection, 2 weeks later rats received $(2 \mathrm{ml} / \mathrm{kg}$ b.wt) $\mathrm{CCl} 4$ orally at 1:1 dilution in corn oil as a promoter of carcinogenic effect. DEN and $\mathrm{CCl} 4$ administration were repeated once again after 1 month from first DEN injection.

Group III: DEN + proanthocyanidins treated group:

Consisted of 15 male rats received DEN in normal saline $(200 \mathrm{mg} / \mathrm{kg}$ b.wt $)$ by I.P injection, 2 weeks later rats received $(2 \mathrm{ml} / \mathrm{kg}$ b.wt) $\mathrm{CCl} 4$ orally at 1:1 dilution in corn oil as a promoter of carcinogenic effect. DEN and $\mathrm{CCl} 4$ administration were repeated once again after 1 month from first DEN injection then treated orally with Proanthocyanidin dissolved in DMSO at a dose level $(100 \mathrm{mg} /$ $\mathrm{kg} \mathrm{b.wt/day).}$

\subsection{Sampling:}

\subsubsection{Blood samples:}

Twenty-four hours fasting after the last dose of the drugs treatment administration, rats were anaesthetized under diethyl ether anesthesia. Blood samples were collected by ocular vein puncture in dry, clean tubes and allowed to clot for 30 minutes and serum was separated by centrifugation at 3000 r.p.m for 15 minute. Serum was taken by automatic pipettes and collected in dry sterile tubes, then kept in deep freeze at $-20{ }^{\circ} \mathrm{C}$ until use for subsequent biochemical analysis. All sera were analyzed for determination of the following parameters: AST, ALP, total bilirubin, albumin, AFP .

\subsubsection{Liver tissue for molecular analysis:}

Briefly, liver tissues were cut, weighed and minced into small pieces, about $0.5 \mathrm{~g}$ of liver tissues were collected from all animals groups, put in eppendorf tubes and were immediately kept in liquid nitrogen and stored at $-80^{\circ} \mathrm{C}$ till RNA extraction. The molecular analysis of the relative gene expression in liver tissues evaluated by reverse transcription polymerase chain reaction (RT-PCR) were: (TNF- $\alpha$, p53 and Cyp2E1 gene).

\subsection{Analysis:}

\subsubsection{Biochemical analysis}

Serum ALT and ALP activities, total bilirubin, albumin and AFP concentrations were determined according to the method described by Schumann et al. (2002), ELAaser and EL-Merzabani, (1975), Young, (1997) and Doumas et al. (1971) and Engall, (1980), respectively.

\subsubsection{Molecular analysis}

Total RNA was isolated from liver tissue of rats using RNeasy Mini Kit (Thermo Qiagen, \#74104) according to the manufacturer's protocol. Following determination of RNA concentration and purity by Quawell nanodrop Q5000 (USA), $5 \mathrm{mg}$ of total RNA from each sample was reverse transcribed using Quantiscript reverse transcriptase. The produced cDNA was used as a template to determine the relative expression of Tumor necrosis factor alpha (TNF- $\alpha$ ), tumor suppressor (P53) and cytochrome P450 2E1 (Cyp2E1) genes using Step One Plus real time PCR system (Applied Biosystem, USA) and 
gene specific primers. The reference gene, ßactin, was used to calculate fold change in target genes expression. The thermal cycling conditions, melting curves temperatures, and calculation of relative expression was done. For the treated groups, assessment of $2-\Delta \Delta \mathrm{Ct}$ determined the fold change in gene expression relative to the control (Livak and Schmittgen, 2001).

Forward and reverse primers sequence for real time PCR.

\begin{tabular}{|c|c|c|}
\hline Gene & $\begin{array}{r}\text { Forward primer } \\
(5-\ldots-13)\end{array}$ & $\begin{array}{r}\text { Reverse primer } \\
\left(5-\ldots--^{-} 3\right)\end{array}$ \\
\hline TNF- $\alpha$ & GCATGATCCGCGACGTGGAA & AGATCCATGCCGTTGGCCAG \\
\hline $\mathrm{p} 53$ & ATGGCTTCCACCTGGGCTTC & TGACCCACAACTGCACAGGGC \\
\hline CYP2E1 & CTCCTCGTCATATCCATCTG & GCAGCCAATCAGAAATGTGG \\
\hline$\beta$-actin & AAGTCCCTCACCCTCCCAAAAG & AAGCAATGCTGTCACCTTCCC \\
\hline
\end{tabular}

2.6. Statistical analysis:

The results were expressed as mean \pm SE using SPSS software program version 16 (SPSS $\odot$ Inc., USA). The data were analyzed using one-way ANOVA to determine the statistical significance of differences among groups. Duncan's test was used for making a multiple comparison among the groups for testing the inter-grouping homogeneity. Values were considered statistically significant when $p<0.05$.

\section{RESULTS}

The obtained results demonstrated in table (1) revealed that, serum ALT and ALP activities, total bilirubin and AFP concentrations were significantly elevated and serum albumin level was significantly decreased in DEN induced liver cancer in rats when compared with the control normal group. Proanthocyanidins treatment to DEN-induced HCC significantly prevented these changes, resulting in a remarkable protection regarding the same parameters with the ability to restore the value of serum ALT, ALP, total bilirubin, albumin and AFP nearly to the average level of control group when compared with DENinduced HCC group.

The obtained qPCR results presented in table (2) revealed a significant up-regulation of TNF- $\alpha$ gene expression level in liver tissue of DEN-induced liver cancer in rats. This expression was significantly downregulated after treatment with Proanthocyanidins. However, a significant downregulation of p53 and Cyp2E1 gene expression levels were observed in liver of DEN induced HCC in rats as compared to the normal control group. This expression was significantly upregulated following treatment by Proanthocyanidins when compared with DEN group.

Table1. Effect of proanthocyanidin treatment on serum ALT and ALP activities, total bilirubin, albumin and AFP concentrations in DEN- induced HCC in rats.

\begin{tabular}{|c|c|c|c|c|c|}
\hline $\begin{array}{l}\text { Parameters } \\
\text { Exp. groups }\end{array}$ & ALT (U/L) & ALP(U/L) & T. bilirubin(mg/dl) & Albumin $(\mathrm{g} / \mathrm{dl})$ & $\mathrm{AFP}(\mathrm{ng} / \mathrm{dl})$ \\
\hline $\begin{array}{l}\text { Group I: } \\
\text { Normal control }\end{array}$ & $190.00 \pm 11.55^{\mathrm{b}, \mathrm{c}}$ & $358.00 \pm 27.14^{b}$ & $0.58 \pm 0.02^{\mathrm{b}}$ & $3.23 \pm 0.12^{\mathrm{a}}$ & $0.73 \pm 0.007^{c}$ \\
\hline $\begin{array}{l}\text { Group П: } \\
\text { DEN }\end{array}$ & $365.00 \pm 14.43^{\mathrm{a}}$ & $490.00 \pm 11.55^{\mathrm{a}}$ & $1.75 \pm 0.03^{\mathrm{a}}$ & $1.80 \pm 0.17^{\mathrm{b}}$ & $4.90 \pm 0.47^{\mathrm{a}}$ \\
\hline $\begin{array}{l}\text { Group III: } \\
\text { DEN+ } \\
\text { Proanthocyanidin }\end{array}$ & $195.00 \pm 2.89^{\mathrm{c}}$ & $389.33 \pm 10.87^{b}$ & $0.85 \pm 0.03^{c}$ & $2.85 \pm 0.08^{\mathrm{b}}$ & $2.37 \pm 0.35^{\mathrm{c}}$ \\
\hline
\end{tabular}

Mean values with different superscript letters in the same column are significantly different at $(\mathrm{P} \leq 0.05)$. 
Table 2. Effect of Proanthocyanidin treatment on liver tissue TNF- $\alpha$, p53 and Cyp2E1 gene expression level in DEN-induced HCC in rats.

\begin{tabular}{lccc}
\hline \multicolumn{1}{c}{ Parameters } & $\begin{array}{c}\text { TNF- } \alpha \\
\text { Fold change mean } \\
\text { SEM }\end{array}$ & $\begin{array}{c}\mathrm{p} 53 \\
\text { Fold change mean } \pm \\
\text { SEM }\end{array}$ & $\begin{array}{c}\text { Cyp2E1 } \\
\text { Fold change mean } \pm \text { SEM }\end{array}$ \\
\hline $\begin{array}{l}\text { Group I: } \\
\text { Normal control }\end{array}$ & $1.00^{\mathrm{d}} \pm 0.09$ & $1.00^{\mathrm{a}} \pm 0.06$ & $1.00^{\mathrm{a}} \pm 0.06$ \\
$\begin{array}{l}\text { Group П: } \\
\text { DEN group }\end{array}$ & $7.52^{\mathrm{a}} \pm 0.36$ & $0.02^{\mathrm{d}} \pm 0.01$ & $0.05^{\mathrm{c}} \pm 0.005$ \\
$\begin{array}{l}\text { Group III: } \\
\begin{array}{l}\text { DEN }+ \\
\text { Proanthocyanidin }\end{array}\end{array}$ & $3.51^{\mathrm{c}} \pm 0.15$ & $1.89^{\mathrm{b}} \pm 0.05$ & $2.41^{\mathrm{b}} \pm 0.13$ \\
\hline
\end{tabular}

Means within the same column carrying different superscript letters are significantly different at $(\mathrm{P} \leq 0.05)$.

\section{DISCUSSION}

Hepatocellular carcinoma (HCC) is a primary malignancy of the liver and occurs predominantly in patients with underlying chronic liver disease and cirrhosis (Alison, 2005). $N$-Nitrosodiethylamine (DEN) causes a wide range of tumors in all animal species and such compounds are hazardous to human health. The formation of reactive oxygen species (ROS) is apparent during the metabolic biotransformation of DEN resulting in oxidative stress. Oxidative stress leads to carcinogenesis by several mechanisms including DNA, lipid and protein damage, change in intracellular signaling pathways and even changes in gene expression (Balamurugan and Karthikeyan, 2012). Also, DEN is a potent hepatic carcinogen agent (Mahmoud and Abdul-Hamid, 2012). On the other hand, Carbon tetrachloride (CCl4) produced hepatocellular adenomas and carcinomas in rats, mice and hamsters in oral studies and in rats and mice by inhalation exposure (Manibusan, 2010). DEN and CCl4 is hydroxylated principally by the ethanol inducible CYP2El (cytochrome P450 system) in liver (Verna et al., 1996; Weber et al.,2003).
The obtained results revealed that, serum ALT and ALP activities, total bilirubin and AFP concentrations were significantly elevated and serum albumin level was significantly decreased in DEN/CCl4 induced liver cancer in rats. $\mathrm{DEN}+\mathrm{CCl} 4$ administration induce extensive necrosis and inflammatory infiltration, clusters of hepatocytes, bile duct proliferation and marked atypia (Abd EL- Hamid et al., 2013) or caused hepatic damage by those two toxicants which reflects instability of liver cell metabolism that led to leakage of theses enzymes to circulation. (Hassan et al., 2014). Similarity, Hemieda et al. (2016) showed that treatment with DENA/CCl4 elevate the values of serum ALT, AST and ALP activities and total bilirubin level and markedly decreased serum total proteins and albumin concentrations. Also, Hashem et al. (2016) confirmed that administration of DEN/CCl4 significantly increased liver weight, relative liver weight, AST, ALT and ALP while, body weight, total protein, albumin and $A / G$ ratio were markedly decreased. Furthermore, Liver is the main site of DEN metabolism, the generation of ROS in the liver is recognized as an important contributor in DEN-induced 
damage (Faten et al.,2014). CCl4 is biotransformed by cytochrome P450 (CYP) enzyme system in the endoplasmic reticulum to produce trichloromethyl free radicals $\left(\mathrm{CCl}{ }^{\bullet}\right)$. Then $\mathrm{CCl} 3$ • leads to elicitation of lipid peroxidation (LPO) and destruction of $\mathrm{Ca}^{2+}$ homeostasis, resulting in cell death (Talib, 2012). Moreover, Borai et al. (2017) displayed that a significant elevation in serum AST, ALT and ALP enzymes activities were observed in DEN-treated group as compared to control normal rats indicating that DEN could induce a damaged effect on liver tissues. The elevation in enzymes activities is due to the rupture in the architecture of cell membrane and the leakage and liberation of enzymes into the serum as a result of carcinogenesis, necrosis and toxicity. Also, ALP indicates alteration in biliary flow. Therefore, during carcinogenesis, these enzymes could be used as biomarkers for HCC response to therapy according to (Tork et al.,2015). Furthermore, Vandenberghe, (1996) reported that hypoalbuminemia may result from liver disorders, which are accompanied by a reduction in albumin synthesis. Albumin is a key component of serum proteins. Also, liver toxicity resulted in decrease serum albumin level (Adams et al.,2005). The results of the present study are in agreement with this finding and demonstrate the decreased functional ability of CCl4-injected rat livers (Saravanan et al., 2006).

Meanwhile, treatment with proanthocyanidins to DEN/CCL4 induced HCC rats caused a significant decrease in serum ALT and ALP activities, and total bilirubin and increase in albumin level when compared with DENCCl4 induced HCC group. These results were agreement with Tantawy et al. (2016) and Ahmed et al. (2015) who showed that coadministration of grape seed extract with CCl4 improved serum AST, ALT, albumin and total protein values nearly within the ranges of these parameters in the control nonintoxicated group. Furethermore, KrisEtherton et al. (2004) revealed that potent protective effect of grape seed extract for hepatocytes against the hepatic damage induced by CCl4. Also, Bagchi et al. (2000) stated that proanthocyanidin which is found in grape seed extract, has a broad spectrum of pharmacological and medicinal properties against oxidative stress. Moreover, Shin and Moon (2010) confirmed that grape skin and seeds extract mixed with normal food to rat, significantly inhibited the elevated activity of serum AST and ALT due to dimethylnitrosamine (DMN)-induced liver injury.

Administration of DEN/CCl4 significantly elevated the serum AFP level when compared to normal rats. Similar data was reported by Borai et al. (2017) and Salama et al. (2017) who recognized that AFP concentration was significantly higher in the DEN-treated group as compared to control normal one. It was reported that in DEN induced hepatocarcinogens caused elevation in AFP level (which is widely used as tumor marker for diagnosis of HCC) associated with the increment in tumor growth and progression (Murugan et al., 2015). Similarity, Hashem et al. (2016) reported that a significant increase in AFP level was showen in $\mathrm{DEN}+\mathrm{CCl} 4$ group. The increase in serum AFP concentration has been used as a clinical marker in the diagnosis and monitoring of HCC (Tork et al., 2015). Moreover, Zaazaa et al. (2018) found that an increase in serum AFP level was observed in DEN-induced $\mathrm{HCC}$ in rats when compared to control group. Additionally, alpha fetoprotein (AFP) is the most commonly used tumor markers for the diagnosis of hepatocellular carcinoma (HCC) which is a unique immune-modulatory glycoprotein, and normally made by the immature hepatocytes in the fetus (oncofetal). Detection of AFP during monitoring of liver 
cancer treatment is well accepted in patients with increased AFP level before therapy. It has been recognized that exposure of animals with DEN increases the circulating AFP level (Sadik et al. et al., 2008).

Treatment with proanthocyanidins to DEN/CCL4 induced HCC rats caused a significant decrease in serum AFP level when compared with DEN/CCL4 induced HCC group. The results approved by Hamza et al. (2015) who investigated that grape seed proanthocyanidins extract showed significant regression in $\alpha$-fucosidase and $\alpha$-fetoprotein levels in HCC bearing group. Also, Rajasekaran et al. (2011) investigated that resveratrol which its composition of grape seed extract reduced AFP level.

The obtained qPCR results revealed significant elevation of TNF- $\alpha$ gene expression level in liver tissue of DEN/CCL4 induced $\mathrm{HCC}$ in rats as compared to the normal control group. Similarity, Kumar et al. (2016) confirmed that TNF- $\alpha$ level significantly upregulatation in DEN treated animals. Also, Habib et al. (2008) demonstrated that elevatation in expression of TNF- $\alpha$ in rats with liver cancer induced by ethionine. Moreover, Song et al. (2013) showed that DEN-induced HCC increased TNF- $\alpha$, such tumor necrosis factor alpha $(\mathrm{TNF}-\alpha)$ is pro-inflammatory cytokines produced by macrophages and it plays an important role under tumor conditions (Lutsiak et al., 2005). It has been reported that TNF- $\alpha$ is an essential factor in tumor promotion (Reuter et al., 2011). Moreever, Hamid et al. (2017) stated that CCl4 elevated proinflammatory cytokines TNF- $\alpha$, IL-6, COX-2 and NFkB. An increased level of TNF- $\alpha$ was also shown to correlate with hepatic inflammation, necrosis, and hepatic failure (Budhu and Wang, 2006).

Treatment with proanthocyanidins to DEN/CCL4 induced HCC rats caused a significant down regulation in TNF- $\alpha$ gene expression and NF-kB gene expression when compared with DEN/CCL4 induced HCC group. This result was supported by Ahmed et al. (2015) who showed that significant down regulation of tumor necrosis factor alpha (TNF- $\alpha$ ) was observed in grape seed extract treated group as compared to HCC induced group. Moreover, Hamza et al. (2018) observed that administration of GSE to HCCinduced groups reversed DEN-2AAF demonstrated a reduction in NF-kB-p65 protein level. In previous study, GSP reduced the growth of skin cancer in nude mice through the suppression of NF-kB activity (Meeran et al., 2009).

The obtained qPCR results revealed significant down regulation of $\mathrm{p} 53$ gene expression level in liver tissue of DEN/CCL4 induced $\mathrm{HCC}$ in rats as compared to the normal control group. Similarity, Loyden et al. (2017) demonstrated that a significant reduction in p53 gene expression in DEN group administration. The $\mathrm{p} 53$ protein acts as a central response to cellular stress or DNA damage by inducing cell cycle arrest, apoptosis, senescence, and other tumorsuppressive actions (Bisteau et al.,2014). Moreover, Khan et al. (2016) stated that decrease in p53 expression induced with $\mathrm{CCl} 4$, which explained that $\mathrm{CCl} 4$ acts as a tumor promoter through increasing the intracellular concentration of ROS necrosis/regeneration and cell proliferation and/or may be due to mutation of p53 led to regarding p53 (Farazi et al., 2006).

Treatment with proanthocyanidins to DEN/CCL4 induced HCC rats caused a significant up-regulation in p53 gene expression when compared with DEN/CCL4 induced HCC group. Similarity, Zhang et al. (2017) displayed that the expression levels of p53 increased in GSP-treated cells which proanthocyanidins induce mitochondrial pathway-mediated apoptosis in human colorectal carcinoma cells. Also, Roy et al. 
(2005) investigated that grape seed extract treatment up-regulate tumour suppressor protein, p53 expression and induced apoptosis in JB6 C141 cells. Moreover, Roy et al. (2005) revealed that the levels of p53 and its activated/phosphorylated form were upregulated after proanthocyandins treatment and that the induction of apoptosis by proanthocyandins is mediated through this protein.

The obtained results revealed significant dysregulation of Cyp2E1 gene expression level in liver tissue of DEN/CCL4 induced HCC in rats as compared to the normal control group. Similarity, Zhang et al. (2013) establish that DEN treatment resulted in significant decrease in the activity of CYP2E1 and CYP1A2. It has been well documented that DEN-induced hepatocarcinogenesis requires metabolic activation by some forms of CYP450, especially CYP2E1. Furthermore, Khan et al. (2016) displayed that significant decrease in CYP 2E1 expression was observed in CCl4-induced hepatotoxicity, who confirmed that reactive oxygen species formed during the biotransformation process of $\mathrm{CCl} 4$ are more reactive and toxic than the parental compound. Biotransformation of $\mathrm{CCl} 4$ occurs in the endoplasmic reticulum and the isoenzyme implicated in this process is CYP2E1 (Knockaert et al.,2012).

Treatment with proanthocyanidins to DEN-CCl4 induced HCC rats caused a significant up-regulation in Cyp2E1 gene expression when compared with DEN-CCl4 induced HCC group. Other medicinal phytochemical plants prompted up-regulation in Cyp2E1 gene expression. Similarly, Khan et al. (2012) showed that the active free radical/intermediate of $\mathrm{CCl}_{4}$ caused a reduction in CYP2E1, which was markedly restored by routine treatment. Also, Zhang et al. (2013) reported that garlic oil elevated Cyp2E1 level after reduced by DEN induction hepatocarciongenisis in rats.

\section{Conclusion}

The current study shown that proanthocyanidins administration led to improvement in liver cells function which caused a marked decrease in serum hepatic marker enzymes (ALT and ALP), total bilirubin and tumor marker AFP and increase serum albumin level. Also, proanthocyanidin can inhibit the proliferation of HCC cells through inducing tumor cell apoptosis via activation of the p53 pathway and detoxification enzyme Cyp2E1 and inhibition of TNF- $\alpha$ overexpression. It could be concluded that, the chemo preventive and apoptotic effect of proanthocyanidin as a powerful natural agents that may be useful as antioxidants and anti-tumor activity in management of hepatocellular carcinoma.

\section{REFERENCES}

Abd El-Hamid, N.M.; Abd El-Ghany, M.I.; Nazmy, M.H. and Amgad, S.W. 2013. Can methanolic extract of Nigella sativa seed affect glyco-regulatory enzymes in experimental hepatocellular carcinoma? Enviroment. Health Prev. Med. 18:49-56.

Adams, L.A.; Lymp, J.F.; St Sauver, J.; Sanderson, S.O.; Lindor, K.D.; Feldstein, A. and Angulo, P. 2005. The natural history of nonalcoholic fatty liver disease: apopulation-based cohort study. Gastroenterology.129(1):113-21.

Alison, M.R. 2005. Liver stem cells: implications for hepatocarcinogenesis. Stem Cell Rev. 1(3):253-60.

Ahmed, H.H.; Abdelfattah, H.M.; Hamza, A.H. And Mahmoud, R.H. 2015. grape seed extract restrains hepatocellular carcinoma: pre-clinical study. Int J 
Pharm Bio Sci April; 6(2): (P) 514 525.

Bagchi, D.; Bagchi, M.; Stohs, S.J.; Das, D.K.; Ray, S.D.; Kuszynsk, C.A.; Joshi, S.S. and Pruess, H.G. 2000. Free Radicals and Grape Seed Proanthocyanidin Extract: Importance in Human Health and Disease Prevention. Toxicology,148, 187-197.

Balamurugan, K. and Karthikeyan, J. 2012. Evaluation of Luteolin in the Prevention of N-nitrosodiethylamine induced Hepatocellular Carcinoma. Using animal model system. Ind $\mathrm{J}$ ClinBiochem., 27(2):157-163.

Budhu, A., Wang, X.W. 2006. The role of cytokines in hepatocellular carcinoma. J Leukoc Biol.; 80:1197-1213.

Bisteau, X.; Caldez, M.J. and Kaldis, P. 2014. The complex relationship between liver cancer and the cell cycle: a story of multiple regulations. Cancers; 6(1): 79-111.

Borai, I.H.; Ghanem, H.M.; Ali, M.M.; AbdelHalim, A.H.; Hegazi, A. E.A.; and Mousa, F.M. 2017. Chemopreventive Effect of Momordicacharantia Extract Against Chemically Induced Hepatocellular Carcinoma in Experimental Animals. RJPBCS 8(2) Page No. 529 ISSN: 0975-8585.

Dumas, B. T.; Watson, W. A. and Biggs, H.G. 1971. Albumin standards and the measurement of serum albumin with bromcresol green. ClinChimActa. Feb 3;258(1):21-30.

EL-Aaser, A. A. and EL-Merzabani, M. M. 1975. Simultaneous determination of 5'-nucleotidase and alkaline activities in serum. Z. Klin. Chem. Klin. Biochem., 13,453.
Engall, E. 1980. Methods in Enzymology, Volume 70, Van Vunakis, H. and Langone, J. J. (eds.), Academic Press, New York, 419-492.

Farazi, P.A.; Zeisberg, M.; Glickman, J.; Zhang, Y.; Kalluri, R. and DePinh, R.A. 2006. Chronic bile duct injury associated with fibrotic matrix micro environment provokes cholangiocarcinoma in p53-deficient mice. Nutri. ;6:6622-66277.

Gold, S.L.; Ames, N.B. and Slone,H.T. 2002. Misconceptions about the causes of cancer. D. Paustenbach, ed., 14151460.

Habib, S.H.M.; Makpol, S.; Hamid, N.A.A.; Das, S.; Ngah, W.Z.W. and Yusof, Y.A.M. 2008. Ginger extract (zingiber officinale) has anti-cancer and antiinflammatory effects on ethionineinduced hepatoma rats. Clinics.;63:807-13.

Hamid, M.; Liu, D.; Abdulrahim, Y.; Liu, Y.; Qian, G.; Khan, A.; Gan, F. and Huang, K. 2017. Amelioration of CCl4-induced liver injury in rats by selenizing Astragalus polysaccharides: Role of proinflammatory cytokines, oxidative stress and hepatic stellate cells. Res Vet Sci. Oct;114:202-211.

Hamza, A.A.; Heeba, G.H.; Elwy, H.M.; Murali, C.; El-Awady, R. and Amin, A. 2018. Molecular characterization of the grape seeds extract's effect against chemically induced liver cancer: In vivo and in vitro analyses. Sci Rep. 19;8(1):1270.

Hamza, A.H.; Abdulfattah, H.M.; Mahmoud, R.H.; Khalil, W.K.; Ahmed, H.H. 2015. Grape Seed Extract Restrains Hepatocellular Carcinoma: Pre-Clinical 
Study: Int J Pharm Bio Sci April; 6(2): $514-525$

Hashem, A.S.; Taha, N.M.; Mandour, A.A.; Lebda, M.A.; Balbaa, M.E.; and ElMorshedy, A.S. 2016. Hepatoprotective Effect of Silymarin and Propolis in Chemically Induced Chronic Liver Injury in Rats: Alexandria J Vet Sci, Apr. 49 (1): 35-43.

Hassan, S.K.; Mousa, A.M.; Eshak, M.G.; Farrag, A.R.H. and Badawi, A.F.M. 2014. Therapeutic and chemopreventive effect of nanocurcumin against diethyl nitrosamine induced hepatocellular carcinoma in rats. Int. J. Pharmcol. Pharmceuit. Sci. 6(3): 54-62.

Hemieda,F.A.E.; Serag,H.M.; El-Baz, E. and Ramadan, S.M.E. 2016. Therapeutic efficacy oflicorice and/or cisplatin against diethylnitrosamine and carbon tetrachloride-induced hepatocellular carcinoma in rats. J Am Sci;12(1):1019].

Khan, R.A.; Khan, M.R. and Sahreen, S. 2012. CCl4-induced hepatotoxicity: protective effect of rutin on $\mathrm{p} 53$, CYP2E1 and the antioxidative status in rat. BMC Complementary and Alternative Medicine 12:178.

Khan, R.A.; Khan, M.R.; Sahreen, S. and Alkreathy, H.M. 2016. Effect of Launaea procumbens extract on oxidative marker, p53, and CYP 2E1: a randomized control study. Food \& Nutrition Research [03 Mar, 60:29790.

Knockaert, L.; Berson, A.; Ribault, C.; Prost, P.E.; Fautrel, A.; Pajaud, J.; Lepage, S.; Lucas-Clerc, C.; Bégué, J.M.; Fromenty, B. and Robin, M. A. 2011. Carbon tetrachloride-mediated lipid peroxidation induces early mitochondrial alterations in mouse liver. Lab Invest. Mar;92(3):396-410.

Kris-Etherton, P.M.; Lefevre, M.; Beecher, G.R.; Gross, M.D.; Keen, C.L. and Etherton, T.D. 2004. Bioactive compounds in nutrition and healthresearch methodologies for establishing biological function: the antioxidant and anti-inflammatory effects of flavonoids on atherosclerosis. Annu. Rev. Nutr., 24: 511-538.

Kumar, R.S.; Kumar, S.V.; Balasubramanian, R; Narayanaperumal, P. and Dharmasivam, $\quad$ M. 2016. Chemopreventive effect of Indigo feralinnaei extract against diethylnitrosamine induced hepatocarcinogenesis in rats. JAPS.6 (11);: 199-209.

Kumar, R.S.; Kumar, S.V.; Balasubramanian, R; Narayanaperumal, P. and Dharmasivam, $\quad$ M. 2016. Chemopreventive effect of Indigo feralinnaei extract against diethylnitrosamine induced hepatocarcinogenesis in rats. JAPS. 6 (11); 199-209.

Kung, C.J.; Curri, S.I.; Forbes, J.S.; James, A. and Ross, A.J. 2010. Liver development, regeneration, and carcinogenesis. Journal of biomedicine and biotechnology., 6(10):1-8.

Livak, K.J. and Schmittgen, T.D. 2001. Analysis of relative gene expression data using real-time quantitative PCR and the $2(-\Delta \Delta \mathrm{Ct})$ method. Methods. ;25:402408.

Loyden, G. V., Martínez, L.P.; Gómez, S.V.; Carreón, J.I.P. and de Sánchez, V.C. 2017. Cancer chemoprevention by an adenosine derivative in a model of 
cirrhosis-hepatocellular carcinoma induced by diethylnitrosamine in rats. Tumor;39(2):1010428317691190.

Lutsiak, M.E.; Semnani, R.T.; De Pascalis, R.; Kashmiri, S.V.; Schlom, J. and Sabzevari, H. 2005. Inhibition of $\mathrm{CD} 4+25+\mathrm{T}$ regulatory cell function implicated in enhanced immune response by low-dose cyclophosphamide. Blood 105: 2862-2868.

Mahmoud, M.S. and Abdul-Hamid, M. 2012. Green tea extract ameliorates Liver and pituitary gland toxicityinduced by diethylnitrosamine in male rats. . J Am Sci., 8(3): 58-71.

Manibusan, M.; Jinot, J.; Kopylev, L.; White, P.; Schlosser, P. and Park, T. 2010. Toxicological review of carbontetrachloride. EPA., (56-23-5):1473.

Mansouri, E.; Panahi, M.; Ghaffari, M.A. and Ghorbani, A. 2011. Effects of grape seed proanthocyanidin extract on oxidative stress induced by diabetes in rat kidney. Iran Biomed J.;15:100106.

Meeran, S.M.; Vaid, M.; Punathil, T. and Katiyar, S.K. 2009. Dietary grape seed proanthocyanidins inhibit 12-Otetradecanoyl phorbol-13-acetatecaused skin tumor promotion in 7,12dimethylbenz(a) anthracene-initiated mouse skin, which is associated with theinhibition of inflammatory responses. Carcinogenesis 30, 520528.

Mukherjee, B.; Ghos, K.M. and Chowdhury, H.M. 2009. Chemically induced hepatocellular carcinoma and stages of development with biochemical and genetic modulation: a Special reference to insulin-like growth factor II and Raf gene signaling. ICMR.,(58):201-219.

Murugan, S.; Ameesh, M.N.; Shilpa, S.; Vishal, B. 2015. Study on the Anticarcinogenic Efficacy of Withaferin-A in DEN Induced Hepatocellular Carcinoma: Morphology and Histopathology. IJHSR 273 Vol.5; Issue: 9; September.

Nakamura, Y.; Tsuji, S. and Tonogai, Y. 2003. Analysis of proanthocyanidins in grape seed extracts, health foods and grape seed oils. J Health Sci; 49: 45-54.

Provincial, F. 2010. Guidelines for canadian drinking water quality: guideline technical document - carbon tetrachloride. ISBN., 2-5.

Rajasekaran, D.; Elavarasan, J.; Sivalingam, M.; Ganapathy, E.; Kumar, A.; Kalpana, K. and Sakthisekaran, D. 2011. Resveratrol interferes with Nnitrosodiethylamine-induced hepatocellular carcinoma at early and advanced stages in male Wistar rats. Mol Med Rep. Nov-Dec;4(6):1211-7.

Reuter, S.; Gupta, S.; Park, B.; Goel, A. and Aggarwal, B. B. 2011. Epigenetic changes induced by curcumin and other natural compounds. Genes Nutr, 6, 93-108.

Roy, A.M.; Baliga, M.S.; Elmets, C.A. and Katiyar, S. K. 2005. Grape seed proanthocyanidins induce apoptosis through p53, Bax, and caspase 3 pathways. Neoplasia. Jan;7(1):24-36.

Sadik, N.A.H.; EL-Maraghy, S.A. and Ismail, M. F. 2008. Diethylnitrosamineinduced hepatocarcinogenesis in rats: possible chemoprevention by blueberries: Afr. J. Biochem. Res. Vol.2 (3), pp. 081-087, March. 
Satir, A.A. 2007. An update on the pathogenesis and pathology of hepatocellular carcinoma. Bahrain Medical Bulletin.,29( 2):1-7.

Schumann, G.; Bonora, R.; Ceriotti, F.; Férard, G.; Ferrero, C.A.; Franck, P.F.H.; Gella, F.J.; Hoelzel, W.; Jørgensen, P.J.; Kanno, T.; Kessner, A.; Klauke, R.; Kristiansen, N.; Lessinger, J.M.; Linsinger, T.P.; Misaki, H.; Panteghini, M.;Pauwels, J.; Schiele, F.;Schimmel, H.G.;Weidemann, G. and Siekmann, L. 2002. IFCC primary reference procedures for the measurement of catalytic activity concentrations of enzymes at $37{ }^{\circ} \mathrm{C}$ : Part 5. Reference procedure for the measurement of catalytic concentration of aspartate-aminotransferase. Clin. Chem. Lab Med. ;40:725-733.

Shin, M. and Moon, J. 2010. Effect of dietary supplementation of grape skin and seeds on liver fibrosis induced by dimethylnitrosamine in rats. Nutr Res Prac;4(5):369e74.

Song, Y.; Jin, S.J.; Cui, L.H.; Ji, X.J. and Yang. 2013. Immunomodulatory Effect of Stichopus japonicus acid Mucopolysaccharide on experimental hepatocellular carcinoma in rats. Molecule. 18(4):7179-7193.

Talib, H. 2012. Ph. D Thesis, FOP, IU, Lucknow.

Tantawy, A.A.; Abd El-Ghany, A.M. and Hussein, M. I. 2016. Histopathological And Immunohistochemical Evaluation of Antifibrogenic Effect of Grape Seed Extract on CCl4-Induced Model of Hepatic Fibrosis. The Egyptian Journal of Hospital Medicine Vol. 65, Page 583- 591.
Tork, O.M.; Khaleel, E.F. and Abdelmaqsoud, O.M. 2015. Altered Cell to Cell Communication, Autophagy and Mitochondrial Dysfunction in a Model of Hepatocellular Carcinoma: Potential Protective Effects of Curcumin and Stem Cell Therapy. APJCP.16.18.8271.

Vandenberghe, J. 1996. Hepatotoxicology: Structure, function and toxicological pathology. In Toxicology: Principles and Applications Edited by Niesink, JM, Vries J, Hollinger MA Vries J, Hollinger MA, 669-721.

Verna, L.; Whysner, J. and Williams, G.M. 1996. N-nitrosodiethylamine mechanistic data and risk assessment: bioactivation, DNA-adduct formation, mutagenicity, and tumor initiation. PharmacolTher ; 71: 57-81.

Weber, L. W.; Boll, M. and Stampfl, A. 2003. Hepatotoxicity and mechanism of action of haloalkanes: Carbon tetrachloride as a toxicological model. Crit. Rev. Toxicol., 33, 105-136.

Young D.S. 1997. Effects of Preanalytical Variables on Clinical Laboratory Tests, 2nd ed. Washington, DC: AACC Press;3-85.

Zaazaa, A.M.; Lokman, M.S.; Shalby, A.B.; Ahmed, H.H. and El-Toumy, S.A. 2018. Ellagic Acid Holds Promise Against Hepatocellular Carcinoma in an Experimental Model: Mechanisms of Action. APJCP.19.2.387.

Zhang, C.; Chen, W.; Zhang, X.; Zheng, Y.; Yu, F.; Liu, Y. and Wang, Y. 2017. Grape seed proanthocyanidins induce mitochondrial pathway-mediated apoptosis in human colorectal carcinoma cells.18 Sep, 14(5):58535860 . 
Hussein et al. (2018). BVMJ-35(2): 612-624

Zhang, C.L.; Zeng, T.; Zhao, X.L. and Xie,

K.Q. 2013. Garlic Oil Attenuated

Nitrosodiethylamine-Induced

Hepatocarcinogenesis by Modulating

the Metabolic Activation and

Detoxification Enzymes. Int J Biol Sci; 9(3):237-245. 